\title{
The Relationship Between Women's Eating and Their Mental Situation
}

\section{La relación entre la alimentación de las mujeres y su situación mental}

\author{
Gözde Latifoglu* \\ Psychological Counselling and Guidance, Near East University, Turquía \\ ORCID: https://orcid.org/0000-0002-7668-618X \\ Öznem Yalçuk \\ Psychological Counselling and Guidance, Turquía \\ ORCID: https://orcid.org/0000-0002-6534-3894
}

Received 12-12-19 Revised 01-25-20 Accepted 04-14-20 On line 04-21-20

*Correspondence

Email: gozde.latifoglu@neu.edu.tr
Cite as:

Latifoglu, G., \& Yalçuk, Ö. (2020). The Relationship

Between Women's Eating and Their Mental Situation.

Propósitos y Representaciones, 8(2), e505. doi:

http://dx.doi.org/10.20511/pyr2020.v8n2.505 


\section{Summary}

This study aims to investigate the relationship of the automatic thoughts, eating attitudes, body mass index and socio-demographic attributes of women between the ages of 18-55 years. The universe of the study consisted of 356 women. The data were collected using a demographic information form, automatic thoughts scale and eating attitude test. The results show indicated that automatic thoughts increased as body mass index increased; and eating attitude increased as negative thoughts increased. The sense of inadequacy and negative self-respect scores of unemployed women were higher than those of employed women. Also, it was concluded that childless women felt more helpless and inadequate than women with a child. The results indicated that single women felt more helpless than married women; the total score of the automatic thought decreased as education level increased; the scores of helpless feeling and negative self-respect of the women having a master's degree were lower than any other education levels. Eating attitudes of unemployed women were higher than employed women, though, body mass index of employed women was higher than unemployed women. Education level of women does not affect their eating attitudes. Body mass index decreases as education level increases. Body mass index and eating attitudes of women are not affected by the fact whether women have a child or not.

Keywords: Automatic Thoughts; Positive/Negative Self-Respect; Feeling Helpless; Sense of Inadequacy; Body Mass Index; Eating Attitude.

\section{Resumen}

Este estudio tiene como objetivo investigar la relación de los pensamientos automáticos, las actitudes alimentarias, el índice de masa corporal y los atributos sociodemográficos de las mujeres entre las edades de 18-55 años. El universo del estudio consistió en 356 mujeres. Los datos se recopilaron mediante un formulario de información demográfica, una escala automática de pensamientos y una prueba de actitud alimentaria. Los resultados muestran que los pensamientos automáticos aumentaron a medida que aumentaba el índice de masa corporal; y la actitud alimentaria aumentó a medida que aumentaron los pensamientos negativos. La sensación de inadecuación y los puntajes negativos de autoestima de las mujeres desempleadas fueron más altos que los de las mujeres empleadas. Además, se concluyó que las mujeres sin hijos se sentían más indefensas e inadecuadas que las mujeres con un hijo. Los resultados indicaron que las mujeres solteras se sentían más impotentes que las casadas; la puntuación total del pensamiento automático disminuyó a medida que aumentó el nivel educativo; Los puntajes de sentimiento de impotencia y autoestima negativa de las mujeres que tienen una maestría fueron más bajos que cualquier otro nivel educativo. Las actitudes alimentarias de las mujeres desempleadas fueron más altas que las mujeres empleadas, aunque el índice de masa corporal de las mujeres empleadas fue más alto que las mujeres desempleadas. El nivel educativo de las mujeres no afecta sus actitudes alimentarias. El índice de masa corporal disminuye a medida que aumenta el nivel educativo. El índice de masa corporal y las actitudes alimentarias de las mujeres no se ven afectadas por el hecho de si las mujeres tienen un hijo o no.

Palabras clave: Pensamientos automáticos; Autoestima positiva/negativa; Sensación de impotencia; Sensación de insuficiencia; Índice de masa corporal; Actitud alimentaria.

\section{Introduction}

It is known that half of the adults in western communities are overweight, and it is more common among women particularly (Attila, 2002). Working women's repetitive and monotonous movements in home environment limit their energy consumption, and so maintaining body composition becomes harder. Women tend to gain weight more than men in terms of body weight percentage (Arslan \& Ceviz, 2007). According to socio-cultural view, women generally have a 
negative body image since childhood, and there is a correlation between body image and mental health (Dökmen, 2009). Body image is a combination of our perceptions and feelings (Oğuz, 2005).

There are researchers stating that disfavor of body image in the eye of women decreases with the age. Bozoklu, (2014) found that women are more content with their body today, and the reason behind is the consciousness about body image and self-evaluation of women based on their success but not the appearance in professional life. Another explanation with regard to women's decreased content of their body is asserted with the objectified body consciousness theory. This theory asserts that the impacts from families, media and different segments of the society cause women's body to get objectified, what is important is not their occupational and personal characteristics but their body, shape of their body, weight and appearance. When women adopt this idea, evaluate themselves by appearance and interiorize this cause them to dislike their own body (Dökmen, 2009).

It is important that individuals have positive thinking about their own body. It is known that thinking negatively about one's own body negatively affects mental health. It was asserted childless women who dislike their own body and appearance experience depression and other kinds of problems more than others (Dökmen, 2009). Cognitive theory of Beck regarding depression asserts that experiences of individuals are determinant in allowing them to create hypotheses or schemas about themselves or the world. When non-functional hypotheses become active, they create negative automatic thoughts (Kara, 2016). Automatic thoughts (irrational thoughts) are cognitive distortions in all people. They may increase or decrease from time to time and their effects on people's life may become instant or long-term. The studies conducted on the relationship between irrational thoughts and mental health indicated that they have negative effect on depression, anxiety, addiction, social relations, and so on areas (Koçöz, 2017).

According to the findings of many researchers, women are more stressful than men, and they perceive the situations that may create stress as dangerous more than men. Self-respect that an individual has is very effective in perceiving and coping with stress. Self-respect is related to emotions of personality, and it contains certain ideas and feelings expressing the identity of that person. In other words, self-respect is the degree to which individuals show self-worth and find themselves precious. Self-respect is the positive or negative attitude of individuals against themselves, and self-respect may differ from higher to lower according to their self-perception. Findings of some researchers indicated that people who have eating disorders have lower selfrespect, and people with lower self-respect are at risk of eating disorders (Erol, Toprak, \& ve Yazic1, 2000).

Eating behaviors are not only necessary for biological and physiological development but they are associated with emotional experiences also. Eating disorder is a psychiatric disorder which may end up on severe eating disorders, threat human life and result in death if no precautions are taken in time.

Some researchers argue on eating much, while others state that it is necessary to take more than a certain amount of calories as a criterion during an attack, and some others assert that not the amount of food but the loss of sense of control of individuals should be taken as a criterion. There has been an increase in eating disorders over the last 50 years. Eating disorders are divided into three groups. By description, BTA-YB (Eating Disorder Not Otherwise Specified) includes clinically different tables, and some information about specific variables apart from some important exceptions. A part of the obese population consists of people with TYB (Binge Eating Disorder). TYB obese patients showed higher psychopathology including especially mood disorders than other normal weight people with TYB. Obesity is a disease caused by the excess of fatty tissue in the body more than casual. It is one of the most important health problems of our century affecting the lifetime and its quality negatively. Obesity is accepted as a psychiatric illness. However, the rate of obesity in psychiatric diseases like depression increases (Kocaman, 
2014). Binge eating is a risk factor for psychological problems of obese people (Bozoklu, 2014). AN (Anorexia Nervosa) and BN (Bulimia Nervosa) are other types of eating disorders. Emotional life, social life and body of a person with eating disorder are damaged because of the abnormalities in eating behavior. If the obsession of a person on his/her weight, food, calories and body has begun to impact their emotions, this person has possibly eating disorder compared to those who show eating disorder occasionally. Although general and social factors, familial factors, developmental factors, life experiences, behavioral, psychological and biological factors have a role in eating disorders among eating disorders risk factors, what reasons exactly influence and how initiate the psychopathology has not yet been clarified.

According to DSM IV, eating disorders are rarely seen to occur alone, and they are most generally accompanied by psychiatric disorders. The psychiatric comorbidity detected to accompany eating disorders is depression primarily, and it was detected to be accompanied by anxiety disorders and substance use disorders (Bozoklu, 2014). Eating disorder is common in western communities generally. The effect of industrialization, change or deterioration of nourishing habits, urban life and media can explain the increase in eating disorders. Other psychiatric disorders contributing to eating disorders are mood disorders, anxiety disorders, substance use disorders and personality disorders. Personality disorder is proclaimed to have a role in the beginning, symptoms and continuation of eating disorders. TYB cases are stated to happen more frequently than $\mathrm{AN}$ and $\mathrm{BN}$ cases. Women have more eating disorders than men do. AN especially is more frequent in women. Mental disorder history in the family is an important factor for eating disorders. OCD, major depression, and generalized anxiety disorders are frequent in the families of YB patients (Semiz, Kavakcı, Yağı, Yontar, \& ve Kugu,2012). TYB is important in terms of its connection with obesity especially. The researches point out that TYB prevalence is $2 \%$ in the society. It is a disorder developing with overweight, and it is more common in women (Değirmenci, 2006).

More than $90.0 \%$ of people having eating disorders are women. The beauty is considered to be related with body weight and shape in western communities, so eating disorders are increasing. Many people follow inappropriate diets and do improper exercises to get lose weight, and losing weight is stimulated all around the world through written and visual media (Aslan, 2004).

Considering body mass index classification of the WHO, body mass index is obtained dividing the body weight (kg) by the square (meter) of length (Kaya, Yılmaz, \& Demirhan, 2016). Furthermore, body weights are investigated under six groups which are weak, normal, overweight, obese, extreme obesity and morbid obesity. Thus, body mass indexes signify; 0-18,4 "weak", 18,5-24,9 "normal", 25,0-29,9 "overweight", 30,0-34,9 "obese", 35,0-44,9 "extreme obesity", 45,0 and above "morbid obesity". Psychiatry comorbidity is related with body mass index. The prevalence of mood disorders in obese population is higher $25 \%$ than normal and overweight population. The studies asserted that the frequency of psychological symptoms in obese people differs by gender factor (Bozoklu, 2014). The researches indicated that women have more problematic eating attitudes, have higher motivation to organize their eating attitudes, while anxiety of men is equal to that of women (Çenesiz, 2015). The main objective of this study is to investigate women's body mass index, automatic thoughts and eating attitudes in terms of sociodemographic attributes. Subgoals of the study based on the main objective are stated below;

Is there any significant correlation between the automatic thoughts scale developed through body mass index values of women and eating attitude test scores?

1- Is there any significant difference between women's body mass index values, developed automatic thoughts scale scores, eating attitude test scores and their marital status?

2- Is there any significant difference between women's body mass index values, developed automatic thoughts scale scores, eating attitude test scores and their education level? 
3- Is there any significant difference between women's body mass index values, developed automatic thoughts scale scores, eating attitude test scores and their employment status?

4- Is there any significant difference between women's body mass index values, developed automatic thoughts scale scores, eating attitude test scores and their status of having a child or not?

\section{Method}

\section{Study Group}

The study group consisted of 356 randomly selected female participants between the ages of 18 55 years. The participants had different professions which were academicians, health care staff, public staff and teachers of primary and secondary school. (The participants came from Near East University Faculty of Education, Cengiz Topel State Hospital, Public Service Commission, Ministry of Finance, Güzelyurt High School, Şehit Turgut Secondary School.)

\section{Data Collection Tools}

The data were collected using a Personal Information Form, an Eating Attitude Test and a Developed Automatic Thoughts Scale. The scales used to collect the data are provided below.

\section{Personal Information Form}

The participants were requested to provide information such as their age, weight and height to determine whether they were appropriate for the criteria of the 18-55 age range, so their body mass index was calculated.

Marital status, education level, whether they were employed or unemployed, whether they had a child or not were among the questions. The sociodemographic information was used and an analysis was carried out to see if there was a significant difference between their body mass index and automatic thoughts and eating attitudes.

\section{Eating Attitude Test (Ytt-40)}

The test was developed by Garner and Garfinkel (1979), and it is a self-report measure which is used all around the world today to measure problematic eating attitudes. The test consisted of 40 questions, and the answers were six point Likert type scale ranging from "always" to "never". For YTT-40, cut-off value was 30 points. Cronbach's Alpha reliability coefficient of the eating attitude test scale was found 0.70 in the study conducted by Savaşır and Erol (yıl?) (Kadıoğlu \& Ergün, 2015). Reliability coefficient was 0,86 in this research.

\section{Developed Automatic Thoughts Scale (Odö-G)}

10 positive and neutral sentences were added to the negative automatic thoughts scale by Kendall et al. to see at which intervals automatic thoughts of individuals came out. This scale was named "Developed Automatic Thoughts Scale", in Turkish ODÖ-G. The scale consisted of 40 items. The 5 point Likert scale items are; $1=$ Never, $2=$ Sometimes, $3=$ Often, $4=$ Very Often, $5=$ Always (Kara, 2016). Zeybek and ve Eroğul (2017) ascertained that the first half test reliability for ODÖ was $r=.97$, alpha reliability coefficient was $r=.96$, and the item total correlation varied between .47 and .78 (Bozkurt, 1998, p; 67). Reliability coefficient was 0,76 in this research. The total score that can be obtained from the scale is obtained by collecting the scores given to each item, while the score of 10 positive or neutral statements is obtained by reverse scoring of these items. Bozkurt (1998) adapted the Developed Automatic Thoughts Scale into Turkish language (Zeybek \& ve Eroğul, 2017). 


\section{Data Analysis}

The data were analysed using SPSS 20.0 software. Pearson correlation analysis was used in data analysis to determine whether there is a significant correlation among Body Mass Index, Eating Attitude Test and Developed Automatic Thoughts Scale.

T-test and One-Way Anova test were used to determine whether there is a significant difference between the total scores of sociodemographic information, eating attitudes, body mass index and automatic thoughts.

\section{Results}

Table 1.

Correlation analysis table of participants' body mass index values, developed automatic thoughts and eating attitude test scores

\begin{tabular}{|c|c|c|c|c|c|c|c|}
\hline & & $\begin{array}{l}\text { Body } \\
\text { mass } \\
\text { index }\end{array}$ & $\begin{array}{l}\text { Negative } \\
\text { Self- } \\
\text { Respect }\end{array}$ & $\begin{array}{l}\text { Sense of } \\
\text { Inability }\end{array}$ & $\begin{array}{l}\text { Feeling } \\
\text { Helpless }\end{array}$ & $\begin{array}{l}\text { Automatic } \\
\text { Thought } \\
\text { Total }\end{array}$ & $\begin{array}{l}\text { Eating } \\
\text { Attitudes } \\
\text { Total } \\
\text { Score }\end{array}$ \\
\hline \multirow{3}{*}{$\begin{array}{l}\text { Body } \\
\text { mass } \\
\text { index }\end{array}$} & Pearson & 1 & .075 & -.021 & .085 & $.116^{*}$ & .037 \\
\hline & $\begin{array}{l}\text { Sig. } \\
\text { tailed })\end{array}$ & & .160 & .698 & .111 & .029 & .489 \\
\hline & $\mathrm{N}$ & 356 & 356 & 356 & 356 & 356 & 356 \\
\hline \multirow{3}{*}{$\begin{array}{l}\text { Negative } \\
\text { Self- } \\
\text { Respect }\end{array}$} & Pearson & .075 & 1 & $.623^{* *}$ & $.792^{* *}$ & $.772^{* *}$ & $.171^{* *}$ \\
\hline & $\begin{array}{l}\text { Sig. } \\
\text { tailed })\end{array}$ & .160 & & .000 & .000 & .000 & .001 \\
\hline & $\mathrm{N}$ & 356 & 356 & 356 & 356 & 356 & 356 \\
\hline \multirow[t]{3}{*}{$\begin{array}{l}\text { Sense of } \\
\text { Inability }\end{array}$} & $\begin{array}{l}\text { Pearson } \\
\text { Correlation }\end{array}$ & -.021 & $.623^{* *}$ & 1 & $.563^{* *}$ & $.569^{* *}$ & $.142^{* *}$ \\
\hline & $\begin{array}{l}\text { Sig. } \\
\text { tailed })\end{array}$ & .698 & .000 & & .000 & .000 & .007 \\
\hline & $\mathrm{N}$ & 356 & 356 & 356 & 356 & 356 & 356 \\
\hline \multirow[t]{3}{*}{$\begin{array}{l}\text { Feeling } \\
\text { Helpless }\end{array}$} & $\begin{array}{l}\text { Pearson } \\
\text { Correlation }\end{array}$ & .085 & $.792^{* *}$ & $.563^{* *}$ & 1 & $.715^{* *}$ & $.126^{*}$ \\
\hline & $\begin{array}{l}\text { Sig. } \\
\text { tailed })\end{array}$ & .111 & .000 & .000 & & .000 & .017 \\
\hline & $\mathrm{N}$ & 356 & 356 & 356 & 356 & 356 & 356 \\
\hline \multirow{3}{*}{$\begin{array}{l}\text { Automatic } \\
\text { Thoughts } \\
\text { Total }\end{array}$} & $\begin{array}{l}\text { Pearson } \\
\text { Correlation }\end{array}$ & $.116^{*}$ & $.772^{* *}$ & $.569^{* *}$ & $.715^{* *}$ & 1 & $.157^{* *}$ \\
\hline & $\begin{array}{l}\text { Sig. } \\
\text { tailed) }\end{array}$ & .029 & .000 & .000 & .000 & & .003 \\
\hline & $\mathrm{N}$ & 356 & 356 & 356 & 356 & 356 & 356 \\
\hline \multirow{3}{*}{$\begin{array}{l}\text { Eating } \\
\text { Attitudes } \\
\text { Total } \\
\text { Score }\end{array}$} & $\begin{array}{l}\text { Pearson } \\
\text { Correlation }\end{array}$ & .037 & $.171^{* *}$ & $.142^{* *}$ & $.126^{*}$ & $.157^{* *}$ & 1 \\
\hline & $\begin{array}{l}\text { Sig. } \\
\text { tailed })\end{array}$ & .489 & .001 & .007 & .017 & .003 & \\
\hline & $\mathrm{N}$ & 356 & 356 & 356 & 356 & 356 & 356 \\
\hline
\end{tabular}


Table 1, shows that there is a positive and significant correlation between body mass index and automatic thoughts according to the correlation analysis. However, there is no significant correlation among body mass index, negative self-respect, sense of inadequacy, feeling helpless and eating attitudes $(p<0,05)$. Nevertheless, there is a positive and strong correlation between the total score of eating attitudes and negative self-respect $(\mathrm{p}<0,05)$. There is a positive and significant correlation between the total scores of sense of inadequacy, feeling helpless and automatic thoughts and the total scores of eating attitudes $(\mathrm{p}<0,05)$.

As the body mass index increases, the total score of automatic thoughts increases. As negative self-respect increases, eating attitudes increase accordingly. It was concluded that having negative self-respect, sense of inadequacy and feeling helpless were not factors to cause body mass index to have an impact on personality positively or negatively. In other words, even though the body mass index is low, normal, overweight or obese, this will not show that such an individual has a negative personality or feels inadequate or helpless. However, we can say that as body mass index increases, negative thoughts of an individual increase. There was no significant correlation between low or high body mass index and eating attitudes. This indicates that having low, normal, overweight or being obese does not impact eating attitudes. That is, eating attitudes do not depend on being overweight or obese. As the total score of sense of inadequacy, feeling helpless and automatic thoughts increased, eating attitudes increased. This supports the finding that negative thoughts, feeling inadequate and helpless affect and increase eating attitudes considerably.

Table 2.

Distribution of one-way analysis of variance of developed automatic thoughts, eating attitudes and body mass index values according to the marital status of participants.

\begin{tabular}{llcc}
\hline & & $\mathbf{N}$ & $\boldsymbol{\mu}$ \\
\hline Automatic Thoughts & Married & 245 & 87.3143 \\
Total score & Single & 80 & 87.7500 \\
& Divorced & 31 & 87.6774 \\
Feeling Helpless & Total & 356 & 87.4438 \\
& Married & 245 & 14.3551 \\
& Single & 80 & 15.7625 \\
Sense of Inability & Divorced & 31 & 14.8065 \\
& Total & 356 & 14.7107 \\
& Married & 245 & 8.0816 \\
Negative Self-Respect & Single & 80 & 8.5500 \\
& Divorced & 31 & 7.6452 \\
Eating Attitudes & Total & 356 & 8.1489 \\
Total & Married & 245 & 27.5592 \\
& Single & 80 & 29.3125 \\
& Divorced & 31 & 27.7097 \\
& Total & 356 & 27.9663 \\
Body mass index & Married & 245 & 16.8653 \\
& Single & 80 & 17.9000 \\
& Divorced & 31 & 18.6129 \\
& Total & 356 & 17.2500 \\
\hline & Married & 245 & 26.0206 \\
& Single & 80 & 23.6840 \\
& Divorced & 31 & 24.1677 \\
& Total & 356 & 25.3342 \\
\hline
\end{tabular}

Table 2, shows that the scores of feeling helpless of single women are higher than those of married and divorced women. Comparing negative self-respect and marital status, it can be concluded that single women have higher negative self-respect scores than married or divorced 
women. The scores of the sense of inadequacy of divorced women are lower than married or single women. Total scores of eating attitudes of divorced women are higher than married and single women. The scores of body mass index of married women are much higher than single and divorced women.

Table 3.

Differentiation of variance of developed automatic thoughts, eating attitudes and body mass index values according to the marital status of participants

\begin{tabular}{llll}
\hline $\mathrm{F}$ & $\mathrm{P}$ & $\mu^{2}$ \\
\cline { 2 - 4 } Marital Status & & & \\
\hline 8.027 & .000 & Body mass index & 187.733 \\
.047 & .954 & Automatic Thoughts Total & 6.651 \\
.714 & .490 & Eating Attitudes & 63.820 \\
1.3 & .25 & Negative Self-Respect & 93,815 \\
3.723 & .025 & Feeling Helpless & 59.884 \\
1.493 & .226 & Sense of Inability & 10.923 \\
\hline
\end{tabular}

Table 3, shows that marital status impacts body mass index significantly $(\mathrm{p}<0.05)$, and there is no significant difference between total scores on eating attitudes and the marital status $(p>0.05)$. Moreover, there is no significant difference between marital status and total scores on automatic thoughts, sense of inadequacy and negative self-respect values. Besides that, there is a significant difference between the score of feeling helpless $(p<0.05)$ and the marital status. The score of feeling helpless $\mathrm{p}<0.05$ shows that there is a significant difference between feeling helpless and the marital status.

Table 4.

Distribution of one-way analysis of variance of developed automatic thoughts, eating attitudes and body mass index values according to the education level of participants

\begin{tabular}{llll}
\hline & & $\mathbf{N}$ & $\boldsymbol{\mu}$ \\
\hline Feeling Helpless & Secondary School & 14 & 17.0714 \\
& High School & 100 & 14.6600 \\
& & & \\
& University & 180 & 14.8944 \\
& Master's Degree & 62 & 13.7258 \\
& Total & 356 & 14.7107 \\
\hline Sense of Inability & Secondary School & 14 & 8.3571 \\
& High School & 100 & 8.3400 \\
& University & 180 & 8.2056 \\
& Master's Degree & 62 & 7.6290 \\
& Total & 356 & 8.1489 \\
\hline Negative Self-Respect & Secondary School & 14 & 32.1429 \\
& High School & 100 & 28.5600 \\
& University & 180 & 28.0500 \\
& Master's Degree & 62 & 25.8226 \\
& Total & 356 & 27.966
\end{tabular}




\begin{tabular}{llll}
\hline Negative Self-Respect & Secondary School & 14 & \\
& High School & 100 & \\
& University & 180 & \\
& Master's Degree & 62 & \\
& Total & 356 & \\
\hline Eating Attitudes & Secondary School & 14 & 18.2857 \\
Total Score & High School & 100 & 18.7100 \\
& University & 180 & 16.5889 \\
& Master's Degree & 62 & 16.5806 \\
& Total & 356 & 17.2500 \\
\hline Body mass index & Secondary School & 14 & 29.1011 \\
& High School & 100 & 26.9924 \\
& University & 180 & 24.7383 \\
& Master's Degree & 62 & 23.5389 \\
& Total & 356 & 25.3342 \\
\hline
\end{tabular}

Table 4, shows the distribution of one-way analysis of variance of developed automatic thoughts, eating attitudes and body mass index values according to the education level of participants. As education level increases, body mass index, total score of automatic thoughts, feeling helpless and negative self-respect values decrease significantly.

Table 5.

Differentiation of variance of developed automatic thoughts, eating attitudes and body mass index values according to the education level of participants

\begin{tabular}{lllll}
\hline & & $\mu^{2}$ & $\mathrm{~F}$ & $\mathrm{P}$ \\
\hline Education Level & Body mass index & 245.781 & 10.959 & .000 \\
& Automatic Thoughts Total & 423.834 & 3.043 & .029 \\
& Eating Attitudes & 111.543 & 1.253 & .290 \\
& Negative Self-Respect & 188.548 & 2.799 & .040 \\
& Feeling Helpless & 48.166 & 2.999 & .031 \\
& Sense of Inability & 7.198 & .981 & .402 \\
\hline
\end{tabular}

Table 5 shows that there is a significant difference between education level and body mass index, automatic thoughts, feeling helpless and negative self-respect values. There is no significant difference between women's education level and the total score of eating attitudes $(p>0.05)$ and sense of inadequacy $(p>0.05)$.

Table 6.

Intergroup t-test distribution of developed automatic thoughts of the participants according to their status of employment

\begin{tabular}{llllll}
\hline & Employed & $\mathrm{N}$ & $\mu$ & $\sigma$ & $\mathrm{s} / \sqrt{\mathrm{n}}$ \\
\hline Automatic Thoughts Total & Yes & 313 & 86.8978 & 11.44282 & .64679 \\
& No & 43 & 91.4186 & 14.37463 & 2.19211 \\
Feeling Helpless & Yes & 313 & 14.4058 & 3.89010 & .21988 \\
\multirow{5}{*}{ Sense of Inability } & No & 43 & 16.9302 & 4.45825 & .67988 \\
& Yes & 313 & 8.0064 & 2.60300 & .14713 \\
Negative Self-Respect & No & 43 & 9.1860 & 3.23122 & .49276 \\
& Yes & 313 & 27.3834 & 7.81025 & .44146 \\
& No & 43 & 32.2093 & 10.19234 & \\
\hline
\end{tabular}


Table 6 shows that unemployed women's total scores on automatic thoughts, feeling helpless, sense of inadequacy and negative self-respect average scores were significantly higher than employed women. In consideration of this knowledge, employed women have more positive thoughts, positive self-respect, and psychologically feel more adequate than unemployed women.

Table 7.

Intergroup t-test distribution of eating attitudes and body mass index of the participants according to their status of employment

\begin{tabular}{llllll}
\hline & Employed & $\mathrm{N}$ & $\mu$ & $\sigma$ & $\mathrm{s} / \sqrt{\mathrm{n}}$ \\
\hline Eating Attitudes & Yes & 313 & 17.0543 & 8.93138 & .50483 \\
Total Score & No & 43 & 18.6744 & 12.61088 & 1.92314 \\
& & & & & \\
Body mass index & Yes & 313 & 25.3620 & 4.82898 & .27295 \\
& No & 43 & 25.1314 & 5.67835 & .86594 \\
\hline
\end{tabular}

Table 7, shows that total scores of eating attitudes of employed women are lower than unemployed women. Body mass index of employed women is higher than that of unemployed women.

Table 8.

T-test analysis of developed automatic thoughts, eating attitudes and body mass index values according to employment status of participants

\begin{tabular}{lccc}
\hline Employed/Unemployed & $\mathrm{F}$ & $\mathrm{P}$ & $\mathrm{t}$ \\
\hline Body mass index & 4.613 & .032 & .287 \\
Automatic Thoughts Total & 3.300 & .070 & -2.350 \\
Eating Attitudes & 5.465 & .020 & -1.055 \\
Negative Self-Respect & 8.268 & .004 & -3.650 \\
Feeling Helpless & 1.137 & .287 & -3.918 \\
Sense of Inability & 8.550 & .004 & -2.701 \\
\hline
\end{tabular}

Table 8 , shows that there is a significant difference between the sense of inadequacy and negative self-respect of women and their status of employment $(\mathrm{p}<0.05)$. There is no significant difference between automatic thoughts and feeling helpless values of women and their status of employment $(p>0.05)$. While this supports the finding that employed women's scores on the sense of inadequacy and negative self-respect are lower than unemployed women, and the status of employment does not contribute to total score of automatic thoughts and feeling helpless.

There is a significant difference between the body mass index and eating attitudes total scores and the status of employment considering participants' body mass index (.032) and total score of eating attitudes. This means that the employment status of women has an effect on the body mass index and eating attitudes. 
Table 9.

Intergroup t-test distribution of developed automatic thoughts, eating attitudes and body mass index values of participants according to their status of having a child or not

\begin{tabular}{lccccc}
\hline & Having a child & $\mathrm{N}$ & $\mu$ & $\sigma$ & $\mathrm{s} / \sqrt{\mathrm{n}}$ \\
\hline Automatic Thoughts Total & Yes & 255 & 87.2588 & 11.45462 & .71732 \\
& No & 101 & 87.9109 & 13.01776 & 1.29532 \\
Feeling Helpless & Yes & 255 & 14.3373 & 3.71261 & .23249 \\
& No & 101 & 15.6535 & 4.65926 & .46361 \\
Sense of Inability & Yes & 255 & 7.9647 & 2.42419 & .15181 \\
& No & 101 & 8.6139 & 3.28929 & .32730 \\
Negative Self-Respect & Yes & 255 & 27.5529 & 7.81353 & .48930 \\
& No & 101 & 29.0099 & 9.28170 & .92356 \\
Eating Attitudes & Yes & 255 & 17.0824 & 8.55028 & .53544 \\
Total Score & No & 101 & 17.6733 & 11.43338 & 1.13766 \\
Body mass index & Yes & 255 & 25.8561 & 4.85393 & .30396 \\
& No & 101 & 24.0163 & 4.90155 & .48772 \\
\hline
\end{tabular}

Table 9, shows the developed automatic thoughts, eating attitudes and body mass index values of participants according to their status of having a child or not. Negative self-respect, sense of inadequacy, feeling helpless scores of childless women are higher than those of women with a child.

Table 10.

T-test analysis of developed automatic thoughts, eating attitudes and body mass index values of participants according to their status of having a child or not

\begin{tabular}{lccc}
\hline Having a child or not & $\mathrm{F}$ & $\mathrm{P}$ & $\mathrm{t}$ \\
\hline Body mass index & .142 & .706 & 3.215 \\
Automatic Thoughts Total & 1.220 & .270 & -.465 \\
Eating Attitudes & 1.471 & .226 & -.532 \\
Negative Self-Respect & 3.746 & .054 & -1.501 \\
Feeling Helpless & 6.331 & .012 & -2.797 \\
Sense of Inability & 9.207 & .003 & -2.047 \\
\hline
\end{tabular}

Table 10, shows that there is a significant difference between feeling helpless and sense of inadequacy and having a child or not, and childless women feel more helpless and inadequate than women with a child. It can be inferred from these results that childless women feel more inadequate and helpless cognitively, so they may become more unhappy than women with a child. It was found that there is no significant difference between the total scores of body mass index, automatic thoughts, the scores of negative self-respect and the status of having a child or not. In other words, having a child or not does not affect women's scores of body mass index values, automatic thoughts, eating attitudes and negative self-respect.

\section{Discussion}

Considering the relationship between body mass index values of women and their scores on developed automatic thoughts and eating attitudes, the results show indicated that automatic thoughts increased as body mass index increased; and eating attitude increased as negative thoughts increased. In a study conducted to investigate eating attitudes and body mass index of obese patients, the significant positive correlation between body mass index and YTT scores in terms of eating attitudes which is psychiatric disorder (Kaya, Yilmaz \& Demirhan, 2016). Another study conducted on the psychopathology of binge eating disorder of obese women indicated that 
binge eating disorder could have a relationship with deterioration of psychosocial functioning, general psychopathology and low quality of life, and a direct relationship with symptoms of depression (Babayiğit, Alçalar \& ve Bahadır, 2013).

Single women were found to be more helpless than married women when developed automatic thoughts and marital status were compared. One study pointed out that marital status is not important alone, but the quality of relationship is more important for fulfilling life satisfaction (Canbulat \& Çankaya, 2014). Married women have higher body mass index values than single and divorced women. As a result of the analyses of a study, no significant differences were observed between the scores of HEI (healthy eating index) and marital status, menopausal age, menarche age, frequency of smoking, number of pregnancy, frequency of using alcohol, number of main meals, meals skipped, and education level (Gübür, 2017).

The results indicated that the total score of the automatic thought decreased as education level increased; the scores of helpless feeling and negative self-respect of the women having a master's degree were lower than other education levels. Oğuz, (2005) stated that problem solving skills of students decrease and consequently, their negative automatic thoughts increase as education level of their parents increases (Tümkaya \& ve İflazoğlu, 2000). Body mass index decreases as education level of women increases. It was discovered in a study that both employed and unemployed women's body shape is protected when education level is higher, and a positive correlational relationship was detected between education level and women's waist circumference (Arslan \& ve Ceviz, 2007).

The sense of inadequacy and negative self-respect scores of unemployed women were higher than those of employed women. In a study investigating the healthy life behaviors of participants and the developed automatic thoughts, eating attitudes and body mass index values according to their status of having a child or not, it was found out that women who have higher education level and are more acknowledged about working life are more successful in protecting their body compositions than housewives (Arslan \& ve Ceviz, 2007). Body mass index of employed women was higher than unemployed women. In a study conducted on the obesity prevalence of housewives and employed women, there was a significant difference between body compositions of the same age and height employed women and housewives in terms of weight body mass index, waist circumference, waist-to-hip ratio, biological age, body fat rate, and body fat weight parameters in favor of employed women, and in terms of lean muscle mass and total body water in favor of housewives (Arslan \& ve Ceviz, 2007). Childless women felt more helpless and inadequate than women with a child. Body mass index of women are not affected by the fact whether women have a child or not. The rate of pregnancy of obese women is higher than normal weight women as stated in a study. An increase was observed after birth in the body weight of many women who perceived themselves as obese or overweight. It is asserted that the increase in fertility induced body weight is one kilogram on average, and the relationship between fertility and body weight is influenced by social and behavioral factors indeed (Konuk \& Şahin, 2005).

As education level increased total score on negative automatic thoughts and body mass index decreased. It was concluded that the scores of helpless feeling and negative self-respect of the women having a master's degree were lower than other education levels. Besides that, the sense of inadequacy and negative self-respect scores of unemployed women were higher than those of employed women, while childless women felt more inadequate and helpless than women with a child. Eating attitudes of unemployed women were higher than those of employed women. Furthermore, body mass index of employed women was higher than unemployed women. In addition, education level of women influenced their eating attitudes; moreover, their body mass index and eating attitudes are not affected by the fact whether they have a child or not. 


\section{Recommendations}

1) To prevent negative thoughts and have consciousness about health, more studies should be carried out about healthy life behaviors and to raise awareness of the society on this matter education seminars should be organized and negative thinking preventive group therapies should be organized too.

2) To raise awareness of childless and unemployed women about their own capabilities and rehabilitate their cognitive automatic thoughts, they should be encouraged to participate in group guidance studies, and to ensure this, guides and psychological counselors should organize group studies.

3) To make unemployed women organize their eating attitudes more consciously and healthily, getting support from a diet expert is suggested.

4) Employed women may participate in several activities except for their work to bring their body mass index value to a healthy value range.

5) Women with a child may get support of an expert and participate in education programs for mothers and children to take precautions against bad habits during the development of their children, keep children away from negative sense and thought and behavior supporting advertisements directing to addictive technological devices and supporting the development of obesity which is one of the biggest health problems today, and make their children more conscious about these facts.

6) This is a study oriented to women only. It is suggested to conduct a more comprehensive study including both genders on this subject.

It is suggested to conduct a more comprehensive study adding body perception scale to body mass index, eating attitudes and automatic thought scales.

\section{References}

Arslan, C., \& ve Ceviz, D. (2007). Ev Hanımı ve Çalışan Kadınların Obezite Prevalansı ve Sağlıklı Yaşam Biçimi Davranışlarının Değerlendirilmesi. Fırat Üniversitesi Sağllk Bilimleri Dergisi, 21(5), 212-219.

Aslan, D. (2004). Beden Algısı ile İlgili Sorunların Yaratabileceği Beslenme Sorunları. Hacettepe Üniversitesi Tip Fakültesi Halk Sağlığı AD, 13(9), 327-329.

Attila, S. (2002). Kadın Sağlığı ve Şişmanlık (Obezite). Sürekli Tıp Ĕ̈itim Dergisi.

Babayiğit, Z., Alçalar, N., \& ve Bahadır, G. (2013). Obez Kadınlarda Tıkanırcasına Yeme Bozukluğunun Psikopatoloji ve Bilişsel Açıdan İncelenmesi. (Orijinal Araştırma) Türkiye Klinikleri, 33(4), 1077-78.

Bozkurt, N. (1988). Lise Öğrencilerinin Okul Başarısızlıklarının Altında Yatan, Depresyonla İlişkili Otomatik Düşünme Kalıpları. (Yayınlanmış Doktora Tezi). Dokuz Eylül Üniversitesi, Eğitim Bilimleri Enstitüsü, İzmir.

Bozoklu, G. (2014). Edirne Kent Nüfusunda Yeme Davranışı ve Etkileyen Faktörler. (Yayınlanmış yüksek lisans tezi). Trakya Üniversitesi, Sağlık Bilimleri Enstitüsü, Edirne.

Canbulat, N., \& Çankaya, Z. (2014). Evli Bireylerin Öznel İyi Olma Düzeylerinin Yordanmas1. Ege Ĕgitim Dergisi, 556-576.

Çenesiz, Z. G. (2015). The Relationship Between Eating Atttudes, Personality Factors, Weight Perception, Self-esteem, Appearance Esteem, And Eating Regulation Motivations Based on Self Determination Theory. The Graduate School of Social Sciences. Middle East Technical University, Ankara.

Değirmenci, T. (2006). Obez Erişkinlerde Benlik Saygısı, Yaşam Kalitesi, Yeme Tutumu, Depresyon ve Anksiyete. Pamukkale Üniversitesi Psikiyatri Anabilim Dalı, Denizli.

Dökmen, Z. (2009). Menapoz, Beden İmgesi ve Ruh Sağlı̆ı. Türk Psikoloji Yazıları, 12(24), 4155. 
Erol, A., Toprak, G., \& ve Yazıcı, F. (2000). Üniversite Öğrencilerinde Yeme Bozukluğu Belirtilerini Yordayıcı Olarak Kontrol Odağı ve Benlik Saygısının Karşılaştırılması. Klinik Psikiyatri, 3, 147-152.

Gübür, M. (2017). Pattents Between 25-30 And 30-40 Body Mass Index Between 18-65 Years Who Apply To A Special Hospital Nutrition And Diet Polıclinic. Master's Thesis. Yeditepe University, İstanbul.

Kara, D. (2016). Stresle Başa Çıkma Stratejileri, Olumsuz Otomatik Düşünceler ve Depresyon Belirtileri İlişkisi. (Yayınlanmış yüksek lisans tezi). Tez No: 441625.

Kaya, A., Yılmaz, A., \& Demirhan, B. (2016). Obez Hastalarda Yeme Tutumu İle Vücut Kitle İndeksi Arasındaki İlişkinin Değerlendirilmesi. Atatürk Üniversitesi Sağlık Bilimleri Enstitüsü, 119.

Kocaman, F. (2014). Obez Bireylerde Sağlıklı Yaşam Biçimi Davranışları ve Sağlıkla İlgili Yaşam Kalitesinin Değerlendirilmesi. (Yayınlanmış yüksek lisans tezi). Bilim

Koçöz, D. (2017). Revisiting Cognitive Distortions and Psychopatology Relatıonshıp: Testing Mediating Roles of Mindfulness And Negatıve Self-Focus Using Structural Equation Modeling. Master of Arts In Psychology. Arel University, İstanbul.

Konuk , İ., \& Şahin, T. K. (2005). Konya Fazilet Uluışık Sağlık Ocağı Bölgesinde 15-49 Yaş Grubu Ev Kadınlarında Obezite Prevalansı ve Risk Faktörleri: Genel Tip Dergisi. Konya, 15(4), 147-155.

Oğuz, G. (2005). Bir Güzellik Miti Olarak İncelik ve Kadınlarla İlgili Beden İmgesi. Selçuk Üniversitesi Illetişim Fakültesi, 4(1), 36.

Semiz, M., Kavakc1, Ö., Yağız, A., Yontar, G., \& ve Kugu, N. (2012). Sivas İl Merkezinde Yeme Bozukluklarının Yaygınlığı ve Eşlik Eden Psikiyatrik Tanılar: Türk Psikiyatri Dergisi. Sivas, 23, 2-7.

Tümkaya, S., \& ve İflazoğlu, A. (2000). Ç.Ü Sınıf Öğretmenliği Öğrencilerinin Otomatik Düşünce ve Problem Çözme Düzeylerinin Bazı Sosyodemografik Değişkenlere Göre İncelenmesi. VIII. Ulusal Eğitim Bilimleri Kongresi, 6(6), 154- 155.

Zeybek, S., \& ve Eroğul, A. (2017). Pozitif Fonksiyonel Tutumlar Ölçeği'nin Psikometrik Özelliklerinin İncelenmesi. Bilişsel Davranışçı Psikoterapi ve Araştırmalar Dergisi, 6(2), 59-66. 